\title{
Peran Bauran Pemasaran Terhadap Keputusan Pembelian Generasi Milenial: Studi Jajanan Tradisional
}

\author{
Ira Mayasari*, Novita Widyastuti Sugeng, Heny Ratnaningtyas \\ Sekolah Tinggi Pariwisata Trisakti Jakarta \\ e-mail: iramayasari@stptrisakti.ac.id
}

\begin{abstract}
This study aims to analyze the effect of the marketing mix of traditional snacks on purchasing decisions. The research method uses multiple regression analysis. The population in this study is the millennial generation in Jakarta. While the sample amounted to 114 respondents. The results of the research partially all the variables of the marketing mix of traditional snacks consisting of product, price, place, promotion, physical facilities, people and processes have a significant effect on purchasing decisions. To reach a large market, traditional snacks must be followed by: (1) Good product quality includes appearance, variety, taste and texture; (2) Price affordability; (3) a strategic place to sell traditional snacks such as in traditional markets, cake shops, school canteens, and food stalls near homes; (4) Advertise traditional snacks on Instagram, Facebook and Twitter; (5) The cleanliness of the place to sell traditional snacks must be paid more attention (6) The service quality of people who sell traditional jayanan products must be better; (7) The processing of traditional snacks is modern so it takes a long time. The suggestion from this research is that the promotion of traditional snacks should be improved, especially in developing social media and traditional snacks innovations.
\end{abstract}

Keywords: Product, Price, Place, Promotion, Physical Facilities, People, Process, Purchase Decision

\begin{abstract}
Abstrak
Penelitian ini bertujuan untuk menganalisis pengaruh bauran pemasaran jajanan tradisional terhadap keputusan pembelian. Metode penelitian menggunakan analisis regresi berganda. Populasi dalam penelitian ini adalah generasi milenial di Jakarta. Sedangkan sampel berjumlah 114 responden. Hasil penelitian secara parsial semua variabel bauran pemasaran jajanan tradisional yang terdiri dari produk, harga, tempat, promosi, sarana fisik, orang dan proses berpengaruh signifikan terhadap keputusan pembelian. Untuk meraih pangsa pasar yang besar, maka jajanan tradisional harus diikuti oleh: (1) Kualitas produk yang baik meliputi penampilan, variasi, rasa dan tekstur; (2) Keterjangkauan harga; (3) Tempat yang strategis dalam menjual jajanan tradisional seperti di pasar tradisional, di toko kue, di kantin sekolah, di warung dekat rumah; (4) Mengiklankan jajanan tradisional di instagram, facebook dan twitter; (5) Kebersihan tempat berjualan jajanan tradisional harus lebih diperhatikan; (6) Kualitas pelayanan orang yang menjual produk jajanan tradisonal harus lebih baik; (7) Pengolahan jajanan tradisional sudah modern sehingga membutuhkan waktu yang tidak lama. Saran dari penelitian ini adalah promosi jajanan tradisional harus lebih ditingkatkan terutama di sosial media yang sedang berkembang ini dan inovasi jajanan tradisional.
\end{abstract}

Kata kunci: Produk, Harga, Tempat, Promosi, Sarana Fisik, Orang, Proses, Keputusan Pembelian 


\section{PENDAHULUAN}

Kebiasaan masyarakat mengkonsumsi variasi makanan jajan tradisonal tentu tidak sekedar dilihat dari jenis produk, harga dan tempat penjualan namun juga selera. Selera inilah yang dapat menentukan konsumen dalam memilih variasi makanan jajan tradisional. Apalagi saat ini tersedia adanya keanekaragaman jajanan yang bernuansa modern, tentu sangat mempengaruhi pilihan akan makanan jajan yang dijual diberbagai tempat baik di pasar tradisional maupun supermarket atau mall (Tumbel et al, 2015).

Melihat keanekaragaman bahan maupun tampilan makanan jajan tradisional menunjukkan bahwa berbagai jenis masih ada pembelinya. Walaupun jika diamati tampilan sebuah jenis kue nampak bahwa wujud tampilan, warna serta berbagai atribut yang ada berubah saat ini. Dengan mempelajari perubahan-perubahan yang terjadi pada variasi konsumsi dan selera masyarakat dapat dilihat bahwa para produsen telah dapat melakukan pengembangan produk baru. Adapun produk baru tersebut dapat berupa produk yang cenderung lebih modern, berorientasi pada bentuk yang lebih cantik, atau praktis yang secara umum lebih berkualitas. Selain itu harga yang lebih dapat terjangkau juga merupakan daya tarik tersendiri (Burhanuddin, 2018).

Apabila dilihat secara lebih mendalam bahwa pendapatan masyarakat juga mempengaruhi variasi konsumsi akan makanan jajan tradisional, dimana tingkat pendapatan merupakan salah satu indikator kelas sosial. Mengingat namanya makanan jajan tradisonal sepertinya dikonsumsi masyarakat tradisional saja namun tidak demikian kenyataannya. Makanan jajan tradisional dapat dinikmati oleh berbagai lapisan masyarakat, mulai dari yang berpendapatan rendah sampai yang tinggi. Sekarang banyak dijumpai berbagai macam makanan jajan tradisional dengan berbagai bentuk dan kualitas yang beragam namun jenis makanan tersebut fungsinya sebagai makanan tambahan atau sering disebut dengan istilah "camilan". Lebih istimewa lagi bahwa makanan jajan tradisional sudah menjadi "makanan ringan" atau "snack" yang dapat disajikan pada berbagai jamuan pertemuan atau rapat-rapat mulai tingkat rukun tetangga sampai pertemuan antar para pejabat penting. Dengan demikian jika dicermati ternyata makanan jajan tradisional sudah memiliki status sebagai pengganti makanan modern. Jadi makanan jajan tradisional tidak lagi dikonsumsi masyarakat pedesaan saja yang tradisional namun juga masyarakat perkotaan (Wicaksono, 2019).

Jajanan tradisional ini sangat penting untuk dilestarikan karena memiliki sisi yang sangat unik dari sisi budaya tradisinya, seperti keunikan dalam mengolah kemasannya yang sedari dulu sudah memakai dedaunan yang dibentuk sedemikian rupa yang menghasilkan bentuk yang unik dan sangat tradisional, walaupun sekarang juga sudah banyak yang bergeser dari bentuk awalnya tetapi masih tetap tidak meninggalkan nilai tradisionalnya (Hakiki, 2019).

Tetapi sekarang ini mulai terjadi pergeseran ke bahan yang lebih praktis sehingga nilai tradisional itu hilang dan tidak lagi memiliki keunikan. Beberapa jajanan pasar ini pun ada yang memiliki keunikan dalam cara makannya. Walaupun jajanan pasar ini memiliki keunikan seperti itu tetapi banyak orang yang sudah melupakan jajanan pasar ini karena tergeser oleh kemajuan jaman, padahal jika dilihat sentra kuliner tradisional bisa dijadikan aset untuk pembangunan dalam bidang pariwisata yang saat ini sedang berkembang. Oleh karena itu maka bisa terbuka peluang untuk membuka bisnis di bidang jajanan pasar tersebut, 
karena selain jajanan pasar itu ternyata memiliki berbagai keunikan dan mengandung unsur tradisi didalamnya yang bisa dilestarikan dan dijadikan aset budaya dan pariwisata tradisionalnya (Harsana et al, 2018).

\section{KAJIAN PUSTAKA}

\section{Generasi Milenial}

Generasi Y dikenal dengan sebutan generasi milenial atau milenium. Ungkapan generasi Y mulai dipakai pada editorial koran besar Amerika Serikat pada Agustus 1993. Generasi ini banyak menggunakan teknologi komunikasi instan seperti email, SMS, instant messaging dan media sosial seperti facebook dan twitter, dengan kata lain generasi $\mathrm{Y}$ adalah generasi yang tumbuh pada era internet booming (Lyons, 2004). Lebih lanjut (Lyons, 2004) mengungkapkan ciriciri dari generasi $\mathrm{Y}$ adalah karakteristik masing-masing individu berbeda, tergantung dimana ia dibesarkan, strata ekonomi, dan sosial keluarganya, pola komunikasinya sangat terbuka dibanding generasi-generasi sebelumnya, pemakai media sosial yang fanatik dan kehidupannya sangat terpengaruh dengan perkembangan teknologi, lebih terbuka dengan pandangan politik dan ekonomi, sehingga mereka terlihat sangat reaktif terhadap perubahan lingkungan yang terjadi di sekelilingnya, memiliki perhatian yang lebih terhadap kekayaan.

Menurut Taylor \& Keeter (2010), karakteristik suatu generasi ditentukan sekurang-kurangnya oleh tiga proses yang tumpang tindih. Pertama, siklus kehidupan. Generasi milenial saat ini yang sebagian besar merupakan populasi muda mempunyai karakter yang berbeda karena usia mereka dan bisa jadi ketika mereka beranjak dewasa dan semakin tua, mereka akan memiliki karakter yang sama dengan generasi lainnya. Kedua, efek periode. Setiap periode disertai dengan beberapa konteks tertentu, entah sosial, politik, kultural, teknologi, dan lain sebagainnya. Ketiga efek pelabelan. Pelabelan generasi dan proyeksi akademik yang dikenakan pada suatu generasi secara tidak sadar membentuk karakter yang khas.

\section{Jajanan Tradisional}

Jajanan pasar adalah makanan tradisional Indonesia yang di perjual-belikan di pasar, khususnya di pasar-pasar tradisional. Atau definisi lain dari jajanan pasar adalah nama lain dari berbagai macam kue yang pada awalnya di perjual-belikan di pasar-pasar tradisional. Seiring perkembangannya, banyak juga hotel berbintang yang tidak malu malu menyajikan kue tradisional ini dengan kue modern lainnya. Hal ini disebabkan oleh karena jajanan pasar memiliki bentuk, cita rasa, tekstur, dan penampilan yang lebih menggoda selera (Sutomo, 2012).

Jajanan pasar dapat dibedakan menjadi menjadi 2 jenis yaitu jajanan pasar tradisional dan jajanan pasar modern. Jajanan pasar tradisional memiliki bentuk, rasa, dan penampilan yang tidak mengalami perubahan atau tetap mempertahankan style asli. Jajanan pasar modern merupakan jajanan pasar tradisional yang dimodifikasi sehingga sebagian atau bahkan seluruh bentuk, rasa, dan penampilannya berubah (Alamsyah, 2008).

Selain jenis jenis jajanan pasar yang beraneka ragam, menurut Sutomo (2012), teknik memasak dari jajanan pasar sendiri juga bervariasi. Makanan jajan tradisional biasanya terbuat dari bahan dasar terigu atau bahan lain selain terigu namun fungsinya pengganti terigu seperti dari beras, beras ketan, tepung ubi kayu atau ubi jalar dan garut. Dengan berbagai macam bahan dasar tersebut dapat dibuat berbagai jenis makanan jajan tradisional seperti kue tok, lemper, 
nagasari, apem, onde-onde, bikang, martabak, bikang, jenang, lapis dan lain-lain.

\section{Konsep Bauran Pemasara}

Dalam bauran pemasaran terdapat seperangkat alat pemasaran yang dikenal dalam istilah 7P, menurut Kotler \& Amstrong (2014) yaitu: (1) Produk atau jasa yang dihasilkan harus memiliki kualitas dan keunikan yang mampu meningkatkan daya saing produk atau jasa di pasaran; (2) Harga, seseorang akan membeli produk jika pengorbanan yang dikeluarkan yaitu uang dan waktu sesuai dengan manfaat yang diinginkan dari produksi barang atau jasa yang ditawarkan; (3) Tempat yaitu lokasi untuk melakukan proses jual beli produk baik barang maupun jasa; (4) Promosi adalah suatu unsur untuk memberitahukan konsumen tentang produk atau jasa yang baru melalui iklan, penjualan pribadi, promosi penjualan, maupun publikasi; (5) Sarana fisik merupakan lingkungan atau bangunan fisik, peralatan, perlengkapan, logo, warna dan barang-barang lainnya; (6) Orang adalah semua pelaku yang memainkan peranan penting dalam penyajian jasa sehingga dapat mempengaruhi persepsi pembeli; (7) Proses adalah semua prosedur aktual, mekanisme, dan aliran aktivitas yang digunakan untuk menyampaikan jasa seperti pelanggan jasa akan senang merasakan sistem penyerahan jasa sebagai bagian jasa itu sendiri.

\section{Keputusan Pembelian}

Keputusan pembelian merupakan pemikiran dimana individu mengevaluasi berbagai pilihan dan memutuskan pilihan pada suatu produk dari sekian banyak pilihan. Menurut Kotler \& Amstrong (2014), keputusan pembelian adalah tahap dalam proses pengambilan keputusan pembeli di mana konsumen benar-benar membeli.
Menurut Tjiptono \& Gregorius (2012), faktor-faktor yang mempengaruhi keputusan pembelian pelanggan adalah ikatan emosional yang terjalin antara pelanggan dan produsen setelah pelanggan menggunakan produk dan jasa dari perusahaan dan mendapati bahwa produk atau jasa tersebut memberi nilai tambah. Dimensi nilai terdiri dari 4 (empat), yaitu: (1) Nilai emosional, utilitas yang berasal dari emosi positif yang ditimbulkan dari mengonsumsi produk; (2) Nilai sosial, utilitas yang didapat dari kemampuan produk untuk meningkatkan konsep dirisosial konsumen; (3) Nilai kualitas, utilitas yang didapat dari produk karena reduksi biaya jangka pendek dan biaya jangka panjang.; (4) Nilai fungsional adalah nilai yang diperoleh dari atribut produk yang memberikan kegunaan kepada konsumen.

\section{Hipotesis Penelitian}

Berdasarkan penelitian Tumbel, et al (2015) bahwa harga, lokasi, keragaman produk dan kualitas berpngaruh signifikan terhadap keputusan pembelian karena Untuk meraih pangsa pasar yang besar, akibat persaingan yang ketat maka harga, lokasi, keragaman produk, dan kualitas merupakan bagian dari strategi yang dapat digunakan, namun hal ini harus juga diikuti oleh kualitas kinerja yang baik.

Penelitian yang dilakukan oleh Natakusumah \& Yuliati (2016), bahwa produk, harga, tempat dan promosi berpengaruh signifikan terhadap keputusan pembelian karena untuk menciptakan bauran pemasaran yang dapat memenuhi keinginan dan kebutuhan konsumen seperti membuat kue berkualitas serta memperbanyak jenis-jenis kue, menawarkan harga yang sesuai dengan kualitas produk, memiliki outlet penjualan dan membuat 
promosi yang dapat menarik perhatian konsumen untuk membeli kue kering.

Wicaksono (2019), penelitiannya menunjukkan bahwa harga, produk, tempat, promosi dan bukti fisik berpengaruh signifikan terhadap keputusan pembelian karena keterjangkauan harga, kesesuaian harga dengan kualitas produk, daya saing harga dan diskon dapat mempengaruhi keputusan pembelian. Tempat atau pendistribusian mengacu pada berbagai aktivitas pemasaran yang berusaha memperlancar dan mempermudah menyalurkan barang dan jasa dari produsen kepada konsumen. Promosi juga sebagai alat untuk mempengaruhi konsumen dalam kegiatan pembelian atau penggunaan produk sesuai dengan kebutuhan dan kerugiannya. Bukti fisik seperti pegawai, interior, lahan parkir dapat mempengaruhi keputusan pembelian. Habibie, et al (2021) dan Mustika, et al (2021) menunjukkan bahwa yang menentukan seseorang berminat membeli barang/jasa adalah dengan melakukan promosi di media sosial karena berhubungan dengan masyarakat banyak yang sudah mengenal teknologi digital.
Marcelina \& Tantra (2017) dan Christine et al (2017) serta Putra \& Saputri (2020) menunjukan bahwa produk, harga, tempat, promosi, sarana fisik, orang dan proses berpengaruh signifikan terhadap keputusan pembelian karena $7 p$ tersebut adalah bauran pemasaran era digital yang sangat diperlukan oleh konsumen untuk dapat memutuskan membeli sebuah produk/jasa yang ditawarkan oleh produsen. Berdasarkan kesimpulan di atas maka hipotesis dalam penelitian ini adalah:

H1 : Adanya pengaruh signifikan produk terhadap keputusan pembelian

H2 : Adanya pengaruh signifikan harga terhadap keputusan pembelian

H3 : Adanya pengaruh signifikan tempat terhadap keputusan pembelian

H4 : Adanya pengaruh signifikan promosi terhadap keputusan pembelian

H5 : Adanya pengaruh signifikan sarana fisik terhadap keputusan pembelian

H6 : Adanya pengaruh signifikan orang terhadap keputusan pembelian

H7 : Adanya pengaruh signifikan proses terhadap keputusan pembelian

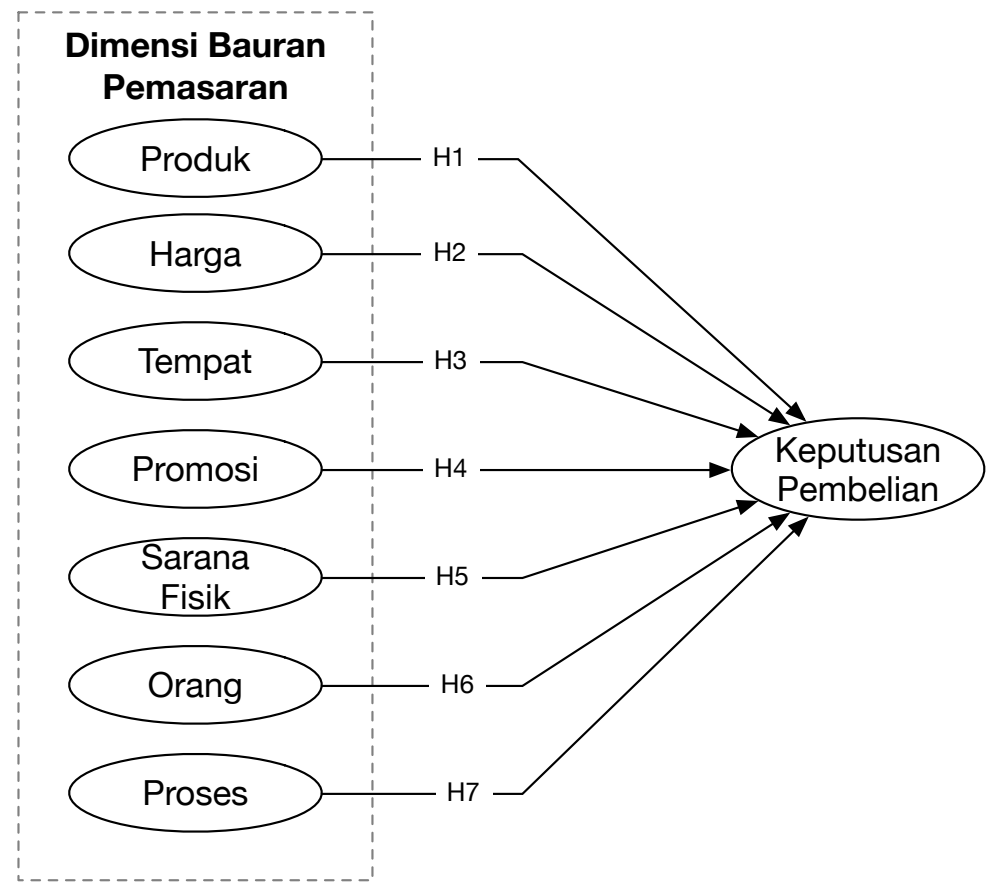

Gambar 1. Kerangka Konseptual 
Tabel 1. Hasil pengujian Validitas dan Reliabilitas Instrumen

\begin{tabular}{|c|c|c|c|c|}
\hline Variabel & Kode & Item Pertanyaan & r-hitung & $\begin{array}{l}\text { Cronbac } \\
\text { h Alpha }\end{array}$ \\
\hline \multirow[t]{5}{*}{ Produk X1 } & $\mathrm{X} 1.1$ & Jajanan tradisional memiliki cita rasa yang enak & 0,763 & 0,898 \\
\hline & $\mathrm{X} 1.2$ & Jajanan tradisional menawarkan banyak varian produk makanan & 0,801 & \\
\hline & $\mathrm{X} 1.3$ & Jajanan tradisional menyajikan tampilan yang rapi dan unik & 0,783 & \\
\hline & $\mathrm{X} 1.4$ & Jajanan tradisional memiliki kesegaran bahan yang baik & 0,804 & \\
\hline & $\mathrm{X} 1.5$ & Jajanan tradisional harus memiliki merek & 0,789 & \\
\hline \multirow[t]{5}{*}{ Harga X2 } & $\mathrm{X} 2.1$ & Jajanan tradisional menawarkan harga sesuai dengan kualitas & 0,757 & 0,925 \\
\hline & $\mathrm{X} 2.2$ & Jajanan tradisional menawarkan harga yang terjangkau & 0,662 & \\
\hline & $\mathrm{X} 2.3$ & Jajajan tradisional menawarkan harga yang kompetitif & 0,756 & \\
\hline & $\mathrm{X} 2.4$ & $\begin{array}{l}\text { Biaya yang dikeluarkan untuk membeli jajanan tradisional sesuai } \\
\text { dengan manfaat dan keuntungan yang diperoleh kaum milenial }\end{array}$ & 0,835 & \\
\hline & $\mathrm{X} 2.5$ & Jajajan tradisional dapat bersaing dengan jajanan kekinian & 0,865 & \\
\hline \multirow{5}{*}{$\begin{array}{l}\text { Tempat } \\
\text { X3 }\end{array}$} & $\mathrm{X} 3.1$ & Jajanan tradisional memiliki tempat penjualan yang nyaman & 0,834 & 0,868 \\
\hline & X3.2 & Jajanan tradisional memiliki tempat penjualan yang bersih & 0,836 & \\
\hline & X3.3 & Jajanan tradisional memiliki tempat penjualan yang strategi & 0,794 & \\
\hline & X3.4 & Jajanan tradisional memiliki tempat penjualan yang mudah diakses & 0,831 & \\
\hline & X3.5 & Jajanan tradisional memiliki tempat penjualan yang mudah dikenali & 0,737 & \\
\hline \multirow{5}{*}{$\begin{array}{l}\text { Promosi } \\
\mathrm{X} 4\end{array}$} & $\mathrm{X} 4.1$ & Jajanan tradisional dapat dipromosikan di Instagram & 0,764 & 0,927 \\
\hline & $\mathrm{X} 4.2$ & Jajanan tradisional dapat dipromosikan di Facebook & 0,666 & \\
\hline & $\mathrm{X} 4.3$ & Jajanan tradisional dapat dipromosikan di status WhatsAPP & 0,720 & \\
\hline & $\mathrm{X} 4.4$ & Jajanan tradisional dapat dipromosikan di Twitter & 0,836 & \\
\hline & $\mathrm{X} 4.5$ & $\begin{array}{l}\text { Jajanan tradisional dapat dipromosikan melalui spanduk di jalan } \\
\text { raya }\end{array}$ & 0,688 & \\
\hline \multirow[t]{5}{*}{$\begin{array}{l}\text { Sarana } \\
\text { Fisik X5 }\end{array}$} & $\mathrm{X} 5.1$ & $\begin{array}{l}\text { Suasana di tempat penjualan jajanan tradisional sangat rapi dan } \\
\text { nyaman }\end{array}$ & 0,767 & 0,874 \\
\hline & X5.2 & Ruangan di tempat penjualan jajanan tradisional sangat bersih & 0,707 & \\
\hline & $\mathrm{X} 5.3$ & Interior tempat penjualan jajanan tradisional sangat menarik & 0,605 & \\
\hline & X5.4 & Jajanan tradisional memiliki ketersediaan dan kebersihan toilet & 0,770 & \\
\hline & $\mathrm{X} 5.5$ & Lahan parkir tempat penjualan tradisional nyaman dan luas & 0,654 & \\
\hline \multirow[t]{5}{*}{ Orang X6 } & X6.1 & Jajanan tradisional memiliki pelayanan yang sangat cepat & 0,669 & 0,729 \\
\hline & X6.2 & Jajanan tradisional memiliki pelayanan yang ramah dan sopan & 0,616 & \\
\hline & X6.3 & Jajanan tradisional memiliki pelayanan yang mudah dipahami & 0,683 & \\
\hline & X6.4 & $\begin{array}{l}\text { Jajanan tradisional memiliki pelayanan yang tanggap dalam } \\
\text { menghadapi keluhan }\end{array}$ & 0,705 & \\
\hline & X6.5 & $\begin{array}{l}\text { Jajanan tradisional memiliki proses dalam memilih makanan yang } \\
\text { nyaman }\end{array}$ & 0,711 & \\
\hline \multirow[t]{5}{*}{ Proses X7 } & X7.1 & Proses pembuatan kue tradisional sangat mudah dan cepat & 0,723 & 0,792 \\
\hline & $\mathrm{X} 7.2$ & Pembungkus produk jajanan tradisional sangat higienis dan rapi & 0,661 & \\
\hline & $\mathrm{X} 7.3$ & $\begin{array}{l}\text { Alat yang digunakan untuk mengambil produk jajanan tradisonal } \\
\text { seperti baki dan penjepi makanan disediakan dengan baik dan rapi }\end{array}$ & 0,632 & \\
\hline & X7.4 & $\begin{array}{l}\text { Penataan produk jajanan tradisional sangat baik dan terstruktur } \\
\text { sehingga tidak menyulitkan konsumen pada saat mencari produk }\end{array}$ & 0,658 & \\
\hline & $\mathrm{X} 7.5$ & $\begin{array}{l}\text { Jajanan tradisional cepat dan mudah melayani pembayaran dengan } \\
\text { uang cash }\end{array}$ & 0,735 & \\
\hline \multirow[t]{5}{*}{$\begin{array}{l}\text { Keputusan } \\
\text { Pembeli }\end{array}$} & Y1 & $\begin{array}{l}\text { Saya membeli produk jajanan tradisional karena sesuai dengan } \\
\text { selera saya yang menyukai kue asli Indonesia }\end{array}$ & 0,819 & 0,702 \\
\hline & Y2 & $\begin{array}{l}\text { Saya yakin dengan kualitas produk jajanan tradisional yang higienis } \\
\text { dan sehat }\end{array}$ & 0,767 & \\
\hline & Y3 & $\begin{array}{l}\text { Saya memilih produk jajanan tradisional karena terjangkau dan } \\
\text { kompetitif }\end{array}$ & 0,822 & \\
\hline & Y4 & $\begin{array}{l}\text { Saya mencari banyak informasi tentang produk jajanan tradisional } \\
\text { dari teman dan saudara saya yang membuat saya yakin untuk } \\
\text { membelinya }\end{array}$ & 0,738 & \\
\hline & Y5 & $\begin{array}{l}\text { Saya yakin akan melakukan pembelian ulang produk jajanan } \\
\text { tradisional }\end{array}$ & 0,771 & \\
\hline
\end{tabular}

Sumber: Data diolah, 2021 


\section{METODE PENELITIAN}

\section{Jenis Penelitian}

Jenis penelitian ini adalah penelitian kualitatif yang dikuantitatifkan dengan menggunakan metode analisis regresi berganda (Arikunto, 2013).

\section{Lokasi dan Waktu Penelitian}

Lokasi penelitian ini adalah di STP Trisakti. Waktu penelitian adalah bulan Agustus-September 2020.

\section{Populasi dan Sampel}

Populasi dalam penelitian ini adalah mahasiswa STP Trisakti. Sampel dalam penelitian ini adalah 114 mahasiswa STP Trisakti yang telah ditentukan oleh peneliti dengan acuan dari teori Sugiono (2017), dimana jumlah sampel minimal 30 responden dan untuk selebihnya akan lebih baik.

\section{Metode Pengumpulan Data}

Metode pengumpulan datanya dengan menggunakan kuisioner menggunakan skala likert terdiri dari: $4=$ Sangat Setuju; $3=$ Setuju; 2 = Tidak Setuju; 1 = Sangat Tidak
Setuju. Menggunakan 4 skala likert karena untuk mengukur sikap, pendapat, dan persepsi seseorang atau kelompok orang tentang fenomena sosial (Sugiyono, 2017). Responden dapat memilih salah satu dari empat alternatif jawaban yang disesuaikan dengan keadaan subjek.

\section{Analisis Data}

Pengujian data dalam penelitian ini menggunakan pengujian hipotesis dengan pendekatan analisis regresi linear berganda. Sebelum data dilakukan pengujian model hipotesis, terlebih dahulu dilakukan analisis validitas dan reliabilitas instrument yang ditunjukkan pada tabel 1. Dari tabel 1 diketahui bahwa seluruh instrument telah memenuhi kriteria uji validitas $(r>0,5)$ dan reliabilitas (alpha cronbach $>0,628$ ).

Selanjutnya akan dilakukan pengujian data dengan uji asumsi regresi linear berganda, yang terdiri dari uji normalitas, multikolinearitas dan autokorelasi yang ditunjukkan pada tabel 2. Dari tabel 2 diketahui bahwa seluruh data yang digunakan dalam panalitian telah memenuhi kriteria yang ditentukan.

Tabel 2. Ringkasan uji Asumsi Klasik

\begin{tabular}{|l|c|c|c|}
\hline \multicolumn{1}{|c|}{ Jenis Pengujian } & Nilai Cut-Off & Nilai Hitung & Keterangan \\
\hline Normalitas & $>0,05$ & $\mathrm{X} 1=0,401$ & Memenuhi \\
& & $\mathrm{X} 2=0,295$ & \\
& & $\mathrm{X} 3=0,599$ & \\
& & $\mathrm{X} 4=0,389$ & \\
& & $\mathrm{X} 5=0,189$ & \\
& & $\mathrm{X} 6=0,106$ & \\
\hline Multikolinearitas (Nilai VIF) & & $\mathrm{X} 7=0,119$ & \\
& & $\mathrm{X} 1=2,109$ & Memenuhi \\
& & $\mathrm{X} 2=3,005$ & \\
& & $\mathrm{X} 3=5,212$ & \\
& & $\mathrm{X} 4=2,243$ & \\
\hline Autokorelasi (Nilai Durbin Watson) & & $\mathrm{X} 5=3,154$ & \\
\hline
\end{tabular}

Sumber: Data diolah, 2021 


\section{HASIL DAN PEMBAHASAN}

\section{Hasil}

Berdasarkan tabel di atas, untuk variabel produk $(\mathrm{X} 1)$, nilai t-hitung $(9,647)>\mathrm{t}$-tabel $(1,96)$ dan nilai probabilitas $0,000>0,05$. Dengan demikian $\mathrm{H} 0$ ditolak dan $\mathrm{Ha}$ diterima yang artinya bahwa produk (X1) secara parsial berpengaruh signifikan terhadap keputusan pembelian (Y). Hal ini berarti kaum milenial akan memutuskan pembelian produk jajanan tradisional karena produk jajanan tradisional tersebut memiliki cita rasa yang enak, menawarkan banyak varian produk, tampilan yang rapi dan unik, kesegaran bahan yang baik dan produk jajanan tradisional pun ada juga yang memiliki merek.

Untuk variabel harga (X2), nilai t-hitung $(2,195)>$ t-tabel $(1,96)$ dan nilai probabilitas $0,000>0,05$. Dengan demikian H0 ditolak dan Ha diterima yang artinya bahwa harga (X2) secara parsial berpengaruh signifikan terhadap keputusan pembelian (Y). Hal ini berarti kaum milenial akan memutuskan pembelian produk jajanan tradisional karena produk jajanan tradisional tersebut menawarkan harga sesuai dengan kualitas, terjangkau, kompetitif, dapat bersaing dengan jajanan kekinian dan biaya yang dikeluarkan untuk membeli jajanan tradisional sesuai dengan manfaat dan keuntungan yang diperoleh kaum milenial.

Untuk variabel tempat (X3), nilai thitung $(3,247)>$ t-tabel $(1,96)$ dan nilai probabilitas 0,015 >0,05. Dengan demikian H0 ditolak dan Ha diterima yang artinya bahwa tempat (X3) secara parsial berpengaruh signifikan terhadap keputusan pembelian (Y). Hal ini berarti kaum milenial akan memutuskan pembelian produk jajanan tradisional karena produk jajanan tradisional tersebut memiliki tempat penjualan yang nyaman, bersih, strategis, mudah diakses dan mudah dikenali.
Untuk variabel promosi (X4), nilai thitung $(3,186)>$ t-tabel $(1,96)$ dan nilai probabilitas 0,047 >0,05. Dengan demikian $\mathrm{HO}$ ditolak dan Ha diterima yang artinya bahwa promosi (X4) secara parsial berpengaruh signifikan terhadap keputusan pembelian (Y). Hal ini berarti kaum milenial akan memutuskan pembelian produk jajanan tradisional karena produk jajanan tradisional tersebut dapat dipromosikan di Instagram, Facebook, status WhatsAPP, Twitter dan dapat juga dipromosikan melalui spanduk di jalan raya.

Untuk variabel sarana fisik (X5), nilai thitung $(4,976)>$ t-tabel $(1,96)$ dan nilai probabilitas $0,031>0,05$. Dengan demikian $\mathrm{H} 0$ ditolak dan Ha diterima yang artinya bahwa sarana fisik (X5) secara parsial berpengaruh signifikan terhadap keputusan pembelian (Y). Hal ini berarti kaum milenial akan memutuskan pembelian produk jajanan tradisional karena tempat penjualan produk jajanan tradisional tersebut sangat rapi dan nyaman, bersih, ketersediaan dan kebersihan toilet yang memadai serta lahan parkir yang luas

Untuk variabel orang (X6), nilai t-hitung $(2,532)>$ t-tabel $(1,96)$ dan nilai probabilitas $0,049>0,05$. Dengan demikian H0 ditolak dan Ha diterima yang artinya bahwa orang (X6) secara parsial berpengaruh signifikan terhadap keputusan pembelian (Y). Hal ini berarti kaum milenial akan memutuskan pembelian produk jajanan tradisional karena produk jajanan tradisional tersebut memiliki pelayanan yang sangat cepat, ramah, sopan, mudah dipahami dan tanggap dalam menghadapi keluhan serta jajanan tradisonal memiliki proses dalam memilih makanan yang nyaman.

Untuk variabel proses (X7), nilai t-hitung $(2,115)>$ t-tabel $(1,96)$ dan nilai probabilitas $0,028>0,05$. Dengan demikian H0 ditolak dan Ha diterima yang artinya bahwa proses 
(X7) secara parsial berpengaruh signifikan terhadap keputusan pembelian (Y). Hal ini berarti kaum milenial akan memutuskan pembelian produk jajanan tradisional karena proses pembuatan produk jajanan tradisional tersebut sangat mudah dan cepat. Kemudian pembungkus jajanan tradisional sangat higienis dan rapi dan alat yang digunakan untuk mengambil produk jajanan tradisonal seperti baki dan penjepi makanan disediakan dengan baik dan rapi. Selanjutnya penataan produk jajanan tradisional sangat baik dan terstruktur sehingga tidak menyulitkan konsumen pada saat mencari produk. Jajanan tradisional cepat dan mudah melayani pembayaran dengan uang cash.

Dari tabel di atas, nilai F-hitung $(60,636)$ $>$ F-tabel $(2,10)$ dan nilai probabilitas 0,000 $<0,05$. Dengan demikian H0 ditolak dan $\mathrm{Ha}$ diterima yang artinya bahwa produk (X1), harga (X2), tempat (X3), promosi (X4), sarana fisik (X5), orang (X6) dan proses (X7) secara bersama-sama berpengaruh signifikan dengan keputusan pembelian (Y). Hal ini berarti kaum milenial akan memutuskan pembelian produk jajanan tradisional karena produk jajanan tradisional sangat memerlukan 7 (tujuh) strategi pemasaran yang dapat menentukan kesuksesan untuk menjual produk jajanan tradisional dalam mengejar profit yang maksimal. Keputusan untuk melakukan 7P ini membantu bisnis jajanan tradisional untuk meningkatkan kelebihan dan mengatasi kekurangan dan menjadi lebih kompetitif dan mudah beradaptasi di pasarnya serta meningkatkan kolaborasi yang menguntungkan antara departemen dan mitra.

Tabel 4. Hasil pengujian hipotesis

\begin{tabular}{|l|c|c|l|}
\hline \multicolumn{1}{|c|}{ Variabel } & Beta & Sig-T & \multicolumn{1}{|c|}{ Keterangan } \\
\hline Konstanta (b0) & & & \\
\hline Produk (X1) & -3.865 & -4.375 & - \\
\hline Harga (X2) & .584 & 9.647 & Signifikan* \\
\hline Tempat (X3) & .143 & 2.195 & Signifikan* \\
\hline Promosi (X4) & .443 & 3.247 & Signifikan* \\
\hline Sarana Fisik (X5) & .291 & 3.186 & Signifikan* \\
\hline Orang (X6) & .249 & 4.976 & Signifikan* \\
\hline Proses (X7) & .287 & 2.532 & Signifikan* \\
\hline $\begin{array}{l}R \text { Square }=0,854 \\
\text { R =0,987 }\end{array}$ & .108 & 2.115 & Signifikan* \\
F-Annova =0,000 & & \\
\hline
\end{tabular}

Sumber: Data diolah, 2021

\section{Pengujian Model dan Hipotesis}

Pengujian hipotesis dalam penelitian ini dilakukan melalui tiga tahapan yang terdiri dari uji-ti, uji-f, dan uji model yang semuanya disajikan pada tabel 4 .

Uji $\mathrm{t}$ bertujuan untuk mengetahui ada atau tidaknya pengaruh satu variabel independen terhadap variabel dependen (secara parsial). Dalam pengujian data penelitian ini, nilai signifikansi (Sig) yang digunakan adalah tingkat signifikansi 5\% atau 0,05. Apabila nilai signifikansi lebih kecil dari tingkat signifikansi 5\% atau 0,05 maka secara parsial arus kas operasi (X1) 
dan ukuran perusahaan (X2) berpengaruh secara signifikan terhadap persistensi laba (Y). Sebaliknya jika nilai signifikansi variabel independen lebih besar dari 5\% atau 0, 05 maka secara parsial arus kas operasi (X1) dan ukuran perusahaan (X2) tidak berpengaruh secara signifikan terhadap persistensi laba (Y).

Berdasarkan tabel 4 menunjukan nilai signifikansi untuk variabel arus kas operasi (X1) sebesar 0,046 yang artinya nilai signifikansi lebih kecil 0,05 maka disimpulkan bahwa variabel arus kas operasi (X1) berpengaruh secara signifikan terhadap persistensi laba atau H1 diterima dan HO ditolak sedangkan nilai signifikansi variabel ukuran perusahaan (X2) sebesar 0,038 yang artinya nilai signifikansi lebih kecil 0,05 maka disimpulkan bahwa variabel ukuran perusahaan (X2) berpengaruh secara signifikan terhadap persistensi laba atau $\mathrm{H} 2$ diterima dan $\mathrm{H} 0$ ditolak.

Uji F digunakan untuk menguji pengaruh independen terhadap variabel dependen secara simultan. Pada penelitian ini, uji F dilakukan dengan membandingkan nilai $\mathrm{F}$ hitung dengan $\mathrm{F}$ tabel. Jika $\mathrm{F}$ hitung lebih besar dari $\mathrm{F}$ tabel maka variabel independen secara simultan berpengaruh terhadap variabel dependen. Berdasarkan uji $\mathrm{F}$ pada tabel 4 menunjukan bahwa $\mathrm{F}$ hitung $=2,353$ lebih besar dari $\mathrm{F}$ tabel $=1,96$ yang artinya variabel arus kas operasi (X1) dan ukuran perusahaan (X2) berpengaruh secara simultan terhadap persistensi laba $(\mathrm{Y})$.

Uji koefisien determinansi dilakukan untuk melihat seberapa besar pengaruh variabel independen menjelaskan variabel dependen yang dalam penelitian ini dilihat melalui nilai Adjusted $\mathrm{R}$ Square. Berdasarkan tabel 4 nilai Adjusted R Square sebesar 0,072 yang berarti menjelaskan bahwa besarnya pengaruh variabel arus kas operasi (X1) dan variabel ukuran perusahaan $(\mathrm{X} 2)$ terhadap persistensi laba (Y) adalah sebesar 7,2\% sedangkan sisanya 92,8\% disebabkan oleh faktor lain diluar variabel yang digunakan dalam penelitian ini.

\section{Pembahasan}

Produk (X1) secara parsial berpengaruh signifikan terhadap keputusan pembelian (Y) oleh generasi milenial di Kota Jakarta karena kemasan produk jajanan tradisional sangat penting dalam memasarkan produk karena merupakan suatu yang terlihat dengan mata dan bersifat menarik sehingga konsumen memiliki keinginan untuk membeli produk tersebut. Kualitas produk tersebut meliputi penampilan, variasi, rasa dan tekstur. Harga (X2) secara parsial berpengaruh signifikan terhadap keputusan pembelian (Y) oleh generasi milenial di Kota Jakarta karena keterjangkauan harga menjadi pertimbangan generasi milenial untuk berwisata kuliner membeli jajanan tradisonal. Tempat (X3) secara parsial berpengaruh signifikan terhadap keputusan pembelian (Y) karena banyak generasi milenial membeli jajanan tradisional dari tempat yang strategis yang mereka sudah ketahui seperti pasar tradisional, toko kue, kantin sekolah, warung dekat rumah. Sementara jajanan tradisional pun sudah dilakukan melalui online. Tapi yang banyak dilakukan oleh generasi milenial di Kota Jakarta ingin mendapatkan jajanan tradisional harus ke toko kue dan pasar tradisional seperti Pasar Kue Subuh Senen dan Pasar Kue Subuh Melawai. Promosi (X4) secara parsial berpengaruh signifikan terhadap keputusan pembelian (Y) karena dengan memberitahukan produk jajanan tradisional melalui iklan di sosial media akan mempengaruhi generasi milenial untuk membeli produk jajanan tradisional tersebut. Mengiklankan jajanan tradisional 
di sosial media seperti instagram, facebook dan twitter akan mempengaruhi minat generasi milenial untuk membeli jajanan tradisional. Penelitian ini sesuai dengan penelitian yang dilakukan oleh Tumbel, et al (2015) dan Natakusumah \& Yuliati (2016) serta Wicaksono (2019) menunjukkan produk, harga, tempat dan promosi berpengaruh signifikan dengan keputusan pembelian.

Sarana fisik (X5) secara parsial berpengaruh signifikan terhadap keputusan pembelian (Y) karena generasi milenial menyukai kebersihan tempat berjualan jajanan tradisional yang berkaitan dengan makanan yang akan dibelinya. Orang (X6) secara parsial berpengaruh signifikan terhadap keputusan pembelian (Y) karena kualitas pelayanan orang yang menjual produk jajanan tradisonal baik di pasar tradisional, toko kue, kantin sekolah, warung dekat rumah sangat ramah, cepat dan nyaman dalam melayani generasi milenial untuk membeli jajanan tradisional. Proses (X7) secara parsial berpengaruh signifikan terhadap keputusan pembelian (Y) karena pengolahan jajanan tradisional sudah tidak kuno lagi dengan menggunakan alat-alat modern seperti electric chopper, food processor, blender, slow cooker, microwave, dan lain-lain. Sehingga efisien dan tidak membutuhkan waktu yang lama. Penelitian ini sesuai dengan penelitian yang dilakukan oleh Marcelina \& Tantra (2017) dan Christine et al (2017) serta Putra \& Saputri (2020) menunjukan bahwa produk, harga, tempat, promosi, sarana fisik, orang dan proses berpengaruh signifikan terhadap keputusan pembelian.

\section{KESIMPULAN DAN SARAN}

Kesimpulan

Adanya pengaruh antara bauran pemasaran dengan keputusan pembelian generasi milenial terhadap jajanan tradisional. Hal ini menunjukkan bahwa 7P merupakan variabel yang sangat mempengaruhi keputusan pembelian jajanan tradisional generasi milenial di kota Jakarta. Untuk meraih pangsa pasar yang besar, akibat persaingan yang ketat antara jajanan tradisional dengan jajanan kekinian maka jajanan tradisional harus diikuti oleh: (1) Kualitas produk yang baik tersebut meliputi penampilan, variasi, rasa, tekstur dan kebersihan; (2) Keterjangkauan harga menjadi pertimbangan generasi milenial untuk membeli jajanan tradisonal; (3) Tempat yang strategis dalam menjual jajanan tradisional seperti di pasar tradisional, di toko kue, di kantin sekolah, di warung dekat rumah; (4) Mengiklankan jajanan tradisional di sosial media seperti instagram, facebook dan twitter akan mempengaruhi minat generasi milenial untuk membeli jajanan tradisional; (5) Kebersihan tempat berjualan jajanan tradisional harus lebih diperhatikan; (6) Kualitas pelayanan orang yang menjual produk jajanan tradisonal harus lebih baik; (7) Pengolahan jajanan tradisional sudah modern sehingga efisien dan membutuhkan waktu yang tidak lama.

\section{Saran}

Berdasarkan kesimpulan tersebut, adapun saran yang diberikan adalah sebagai berikut. Sebagian besar generasi milenial melakukan keputusan membeli jajanan tradisional karena kualitas produk dan harga, maka bagi pengelola yang menjual jajanan tradisional diharapkan dapat meningkatkan kualitas produk meliputi penampilan, variasi, rasa, tekstur dan kebersihan. Kemudian harga harus dapat terjangkau oleh kaum milenial.

Kekurangan dari penelitian ini adalah lokasi penelitian hanya di STP Trisakti, oleh karena itu untuk peneliti selanjutnya sebaiknya memilih lokasi yang berbeda dan 
responden yang berbeda pula yang mampu menjelaskan fenomena yng berbeda pula. Diharapkan peneliti selanjutnya dapat menggembangkan penelitian ini dengan meneliti faktor lain yang dapat mempengaruhi keputusan pembelian.

\section{DAFTAR PUSTAKA}

Alamsyah, Yuyun. (2008). Bangkitnya

Bisnis Kuliner Tradisional: Meraih

Untung dari Bisnis Masakan Tradisional

Kaki Lima sampai Restoran. Jakarta :

Gramedia.

Arikunto, S. (2013). Prosedur Penelitian:

Suatu Pendekatan Praktik.

Jakarta: Rineka Cipta.

Burhanuddin, N. H. (2018). Strategi

Pemasaran Makanan Khas Tradisional di

Kecamatan Wotu. Journal of Islamic

Management and Business, 1(2): 20-32.

Christine \& Budiawan, W. Analisis

Pengaruh Marketing Mix (7P) terhadap

Minat Beli Ulang Konsumen (Studi pada

House of Moo, Semarang). Industrial

Engineering Online Jourrnal, 6(1): 1-8.

Habibie, F. H., Mustika, A., Ratnaningtyas,

H., \& Noveti, H. (2021). Promotion of

Instagram and Purchase Intention: A

Case of Beverage Business at Covid-19

Pandemic. (TRJ) Tourism Research

Journal, 5(1): 78-96.

Hakiki, N. N. (2019). Penganekaragaman

Kue Basah Tradisional Berbasis Tepung

Premix. E-journal Tata Boga, 8(1): 99-

105.

Harsana, M., Baiquni, M., Harmayani, E.,

Widyaningsih, Y. A. (2018). Potensi

Makanan Tradisional Kue Kolombeng

Sebagai Daya Tarik Wisata Di Daerah

Istimewa Yogyakarta. HEJ (Home

Economic Journal), 1(2): 40-47.

Kotler, P., \& Amstrong, G. (2014). Prinsip-
Prinsip Pemasaran. Jakarta: Erlangga.

Lyons, S. (2004:441). An exploration of generational values in life and at work.

ProQuest Dissertations and Theses.

Diakses dari

http://ezproxy.um.edu.my/docview/3052

03456 ? accountid $=28930$ pada tanggal 15

Desember 2019.

Marcelina, J., \& Tantra, B. (2017). Pengaruh

Marketing Mix (7p) Terhadap

Keputusan Pembelihan Pada Guest

House di Surabaya. Jurnal Hospitality

dan Manajemen Jasa, 5(2): 1-16.

Mustika, A., Hendradewi, S., \&

Ratnaningtyas, H. (2021). Halal Label:

Is It Important In Determining Buying

Interest?. JIMFE (Jurnal Ilmiah

Manajemen Fakultas Ekonomi), 7(1): 110.

Natakusumah, F. A., \& Yuliati, A. L.,

(2016). Pengaruh Bauran Pemasaran

Terhadap Keputusan Pembelian (Studi

Pada Ina Cookies Bandung). Jurnal

Manajemen Teori dan Terapan, 9(1): 3449.

Putra, D. A., \& Saputri, M. E. (2020).

Pengaruh Bauran Pemasaran Terhadap

Keputusan Pembelian Tiket Online

Angkutan Kereta Api (Studi Pada

Stasiun Bandung). e-Proceeding of

Management, 7(1): 1211-1218.

Sugiyono. (2017). Metode Penelitian

Kuantitatif, Kualitatif, dan R\&D.

Bandung: Alfabeta, CV.

Sutomo, B. (2012). Rahasia Sukses

Membuat Cake, Roti, Kue Kering dan

Jajan Pasar. Jakarta: Nsbooks.

Taylor, P., \& Keeter, S. (2010). Millenials,

A Portrait of Generation Next:

Confident, Connected, Open to Change,

Pew Research Center.

Tjipjono, F., \& Gregorius, C. (2012),

Pemasaran Strategik. Yogyakarta: BPFE. 
Tumbel, A. L., Rate, P. V. (2015). Pengaruh Bauran Pemasaran Terhadap Keputusan Pembelian di Pasar Tradisional (Studi Pada Pasar Tradisonal di Kota Manado). Jurnal LPPM Bidang EkoSosBudKum, 2(20): 60-72.
Wicaksono, I. S. (2019). Pengaruh Bauran Pemasaran Terhadap Keputusan Pembelian Pada Toko Kue Purimas 3 Surabaya. Jurnal Ilmu dan Riset Manajemen, 8(5): 1-18.. 